\title{
Effect of Dietary Supplementation of Critical Amino Acids and Multi- Enzyme with Low Protein and Energy Diet on Carcass and Blood Biochemical Performance of Broiler Chicken
}

\author{
Dhiraj Sawai $^{1 *}$, Gajanan Jadhao ${ }^{1}$, Kalpana Pawar ${ }^{1}$, Atul Dhok ${ }^{2}$ and Roshan Sarode ${ }^{3}$ \\ ${ }^{1}$ Department of Animal Nutrition, Post Graduate Institute of Veterinary and Animal Sciences, Akola (MS), INDIA \\ ${ }^{2}$ Nagpur Veterinary College, Nagpur (MS), INDIA \\ ${ }^{3}$ Indian Veterinary Research Institute, Barely (UP), INDIA \\ *Corresponding author: D Sawai ; Email:dhiraj.sawai@gmail.com
}

Received: 02 March, 2020

Revised: 05 April, 2020

Accepted: 07 April, 2020

\begin{abstract}
The experiment was conducted to study the effect of dietary supplementation of critical amino acids and multi-enzyme with reduced levels of energy and protein diet on carcass and blood biochemical performance in broiler chicken. Three hundred broiler chicks were allotted to five dietary treatments of three replications and 20 birds in each replication. The control $\left(\mathrm{T}_{0}\right)$ were fed with standard diet, $\mathrm{T}_{1}$ (5\% low CP and energy than standard with balancing of lysine and methionine), $\mathrm{T}_{2}\left(\mathrm{~T}_{1}+\right.$ Multi-enzyme), $\mathrm{T}_{3}$ (10\% low CP and energy than standard with balancing of lysine and methionine), $\mathrm{T}_{4}\left(\mathrm{~T}_{3}+\right.$ Multi-enzyme). The dressing percentage and edible meat percentage were significantly more in $\mathrm{T}_{2}$ group. The breast meat percentage of the control group was comparable with $\mathrm{T}_{2}$ group. The result showed that the significantly higher $(\mathrm{P}<0.05)$ gizzard weights in groups receiving enzyme combination supplementation as compared to control group $\left(\mathrm{T}_{0}\right)$ irrespective of the energy-protein levels. The mean value of total protein, albumin, globulin and blood urea nitrogen of all the experimental birds were found to be statistically similar with that of the control group. The treatment group $\mathrm{T}_{2}$ found to be effective and economical.
\end{abstract}

Keywords: Amino acids, Lysine, Methionine, Carcass, Blood Biochemicals

Ensuring feed availability at affordable prices is the key concern for the poultry industry as $70 \%$ of production costs being in the form of feed. Maize and soy meal forms the major proportion of poultry feed with maize contributing $55-65 \%$ and out of the total feed volume soy meal forming $25-30 \%$. There is increased competition between human and animals for these ingredients; moreover India is a net exporter of both these commodities. Therefore the gap between demand and supply is anticipated to broaden more in the coming years, creating a compelling intention to explore the convenience of locally accessible, unconventional feedstuffs in poultry diet formulation. The industry also uses feed additives such as vitamin premixes, amino acids and exogenous enzymes which are largely procured from indigenous sources. Enzyme supplementation in ration breaks down fibrous cell wall, reduces digest a viscosity and increases availability of nutrients. Enzyme addition to corn-SBM diets are frequently reported to increase ileal nutrient digestibility and feed efficiency (Cowieson and Ravindran, 2008). The positive effects of the enzymes are suggested to be due to enhancement of nutrient digestibility in young chicks as well as digestion of soluble and insoluble NSP in corn and SBM. Amino acids in general are critical for muscle development and lysine is known to exhibit specific effects on carcass composition of broilers. Lysine not only increases protein synthesis but also decreases protein catabolism (Kidd et al., 2001). Breast muscle provides the greatest portion of edible meat in broilers and

\footnotetext{
How to cite this article: Sawai, D., Jadhao, G., Pawar, K., Dhok, A. and Sarode, R. (2020). Effect of dietary supplementation of critical amino acids and multi-enzyme with low protein and energy diet on carcass and blood biochemical performance of broiler chicken. J. Anim. Res., 10(3): 423-426 Source of Support: None; Conflict of Interest: None क्)
} 
the contribution of breast muscle to total carcass meat is approximately 30 percent of total carcass meat and would contribute close to 50 per cent of total edible carcass protein (Summers et al., 1988). Similarly, the dietary lysine and methionine inadequacy has been shown to reduce breast muscle yield as compared with other muscles. There are reports indicating that lysine can modify abdominal fat deposition. Methionine acts as a lipotropic agent through its role as an amino acid in balancing protein or through its role as a methyl donor and involvement in choline, betaine, folic acid, and vitamin $\mathrm{B}_{12}$ metabolism (Garcia et $a l ., 2000)$. Therefore, fulfilling dietary amino acid needs for optimum growth and meat yield has been recognized to be of utmost importance in broiler chicken (Dozier et al., 2007).Hence, the present study was planned to offer low protein and low energy diet supplemented with L-lysine, DL-methionine and multienzyme to meet adequate quantity of these amino acids as per BIS (2007) to broiler chicken and to study its effect on their performance of broilers.

\section{MATERIALS AND METHODS}

The present research work was undertaken at Poultry Research Centre, Post Graduate Institute of Veterinary and Animal Sciences, Akola (MAFSU, Nagpur) during the period from 15 ${ }^{\text {th }}$ March 2017 to $26^{\text {th }}$ April 2017. Three hundred commercial, unsexed, straight run, day old Vencobb-400Y broiler chicks belonging to same hatch were procured from Venkateshwara Hatcheries Pvt. Ltd., Pune. On arrival, chicks were weighed individually and assigned randomly into five dietary treatments of three replications and 20 birds in each replication. The control $\left(\mathrm{T}_{0}\right)$ were fed with standard diet as per BIS (2007), $\mathrm{T}_{1}$ (5\% low CP and energy than standard with balancing of lysine and methionine), $\mathrm{T}_{2}\left(\mathrm{~T}_{1}+\right.$ Multienzyme $), \mathrm{T}_{3}(10 \%$ low $\mathrm{CP}$ and energy than standard with balancing of lysine and methionine), $\mathrm{T}_{4}\left(\mathrm{~T}_{3}+\right.$ Multienzyme). The birds were reared on a deep litter system for 6 weeks on standard managemental practices. The blood biochemicals were studied at the end of experiment for serum total protein, albumin, globulin and BUN on Auto-analyzer by using kits of span diagnostic Ltd. Total thirty birds were sacrificed, six birds from each dietary treatment i.e. two birds from each replicate were slaughtered by standard procedure at the end of the experimental period to study the carcass characteristics. The data was analyzed by using Statistical
Package for the Social Sciences (SPSS) Version 17.0. The differences between means were subjected to ANOVA by univariate analysis using General Linear Model. The Significant differences among treatment means were separated by using Duccan's Multiple Range test and considered as significant when $\mathrm{P}-$-value was less than 0.05 .

\section{RESULTS AND DISCUSSION}

Table 1: Blood biochemical observations

\begin{tabular}{|c|c|c|c|c|}
\hline Treatment & Total protein & Albumin & Globulin & BUN \\
\hline $\mathrm{T}_{0}$ & 7.44 & 3.15 & 4.29 & 4.23 \\
\hline $\mathrm{T}_{1}$ & 6.29 & 2.68 & 3.61 & 4.46 \\
\hline $\mathrm{T}_{2}$ & 6.30 & 3.73 & 2.56 & 3.83 \\
\hline $\mathrm{T}_{3}$ & 6.08 & 2.41 & 3.66 & 3.20 \\
\hline $\mathrm{T}_{4}$ & 7.71 & 2.50 & 5.21 & 3.14 \\
\hline Mean & 6.77 & 2.90 & 3.87 & 3.78 \\
\hline
\end{tabular}

Table 2: Average percent carcass yield in broilers at the end of 6th week of age

\begin{tabular}{lllll}
\hline Treatment & $\begin{array}{l}\text { Dressing } \\
(\%)\end{array}$ & $\begin{array}{l}\text { Edible meat } \\
(\%)\end{array}$ & $\begin{array}{l}\text { Giblet } \\
\text { meat (\%) }\end{array}$ & $\begin{array}{l}\text { Abdominal } \\
\text { fat (\%) }\end{array}$ \\
\hline $\mathrm{T}_{0}$ & $80.2^{\mathrm{a}}$ & $75.66^{\mathrm{ab}}$ & $4.53^{\mathrm{abc}}$ & $1.46^{\mathrm{a}}$ \\
$\mathrm{T}_{1}$ & $81.01^{\mathrm{a}}$ & $76.82^{\mathrm{a}}$ & $4.18^{\mathrm{c}}$ & $1.33^{\mathrm{a}}$ \\
$\mathrm{T}_{2}$ & $80.51^{\mathrm{a}}$ & $76.27^{\mathrm{ab}}$ & $4.24^{\mathrm{bc}}$ & $1.44^{\mathrm{a}}$ \\
$\mathrm{T}_{3}$ & $77.76^{\mathrm{ab}}$ & $72.91^{\mathrm{ab}}$ & $4.85^{\mathrm{ab}}$ & $0.91^{\mathrm{b}}$ \\
$\mathrm{T}_{4}$ & $76.43^{\mathrm{a}}$ & $71.52^{\mathrm{b}}$ & $4.91^{\mathrm{a}}$ & $0.9^{\mathrm{b}}$ \\
\hline Pooled mean & 79.18 & 74.63 & 4.54 & 1.21 \\
\hline
\end{tabular}

Treatments end in column bearing common superscripts does not differ significantly $(\mathrm{P}<0.05)$.

The values pertaining to total protein were found to be non-significant. Treatment group $\mathrm{T}_{4}$ shows numerically highest value among all the treatment groups. Plasma protein has been considered as an index of dietary protein intake (Annongu, 1997). Therefore quality and quantity of dietary protein in any diet are expected to influence blood protein concentration. The findings of present study are well corroborated with Awed et al. (2014) who observed reduction in protein level with amino acid supplementation. Similarly Malmo et al. (2013) observed reduction in serum protein in $20 \%$ crude protein diet supplemented with lysine and methionine. For serum albumin it was observed from the table that the control group $\mathrm{T}_{2}$ recorded 
Table 3: Average carcass yield ( $\mathrm{g}$ ) in broilers at the end of $6^{\text {th }}$ week of age

\begin{tabular}{lllllll}
\hline Treatment & Fasting Body Wt & After Bleeding Wt & Defeathering Wt & Eviscerate Wt & Giblet wt & Edible wt \\
\hline $\mathrm{T}_{0}$ & $1782.33^{\mathrm{bc}}$ & $1728^{\mathrm{bc}}$ & $1646.83^{\mathrm{bc}}$ & $1429.33^{\mathrm{c}}$ & $80.91^{\mathrm{NS}}$ & $1348.42^{\mathrm{ab}}$ \\
$\mathrm{T}_{1}$ & $1882.17^{\mathrm{b}}$ & $1822.33^{\mathrm{b}}$ & $1718.67^{\mathrm{b}}$ & $1526.83^{\mathrm{b}}$ & $78.65^{\mathrm{NS}}$ & $1448.18^{\mathrm{b}}$ \\
$\mathrm{T}_{2}$ & $2072^{\mathrm{a}}$ & $1998.17^{\mathrm{a}}$ & $1912.5^{\mathrm{a}}$ & $1668.33^{\mathrm{a}}$ & $87.76^{\mathrm{NS}}$ & $1580.58^{\mathrm{a}}$ \\
$\mathrm{T}_{3}$ & $1668^{\mathrm{c}}$ & $1600.67^{\mathrm{c}}$ & $1516.17^{\mathrm{c}}$ & $1298^{\mathrm{c}}$ & $80.61^{\mathrm{NS}}$ & $1217.39^{\mathrm{c}}$ \\
$\mathrm{T}_{4}$ & $1790.5^{\mathrm{bc}}$ & $1707.33^{\mathrm{bc}}$ & $1620.67^{\mathrm{bc}}$ & $1364.17^{\mathrm{c}}$ & $88.24^{\mathrm{NS}}$ & $1275.93^{\mathrm{c}}$ \\
Pooled mean & 1839 & 1771.3 & 1682.97 & 1457.33 & 83.23 & 1374.1 \\
\hline
\end{tabular}

Treatments end in column bearing common superscripts does not differ significantly $(\mathrm{P}<0.05)$.

Table 4: Percent ingredient composition of broiler diet

\begin{tabular}{llllllllllllllll}
\hline \multirow{2}{*}{\multicolumn{1}{c}{ Ingredients }} & \multicolumn{1}{c}{ Pre-starter } & \multicolumn{1}{c}{ Starter } & \multicolumn{4}{c}{ Finisher } \\
\cline { 2 - 7 } & $\mathbf{T}_{\mathbf{0}}$ & $\mathbf{T}_{\mathbf{1}}$ & $\mathbf{T}_{\mathbf{2}}$ & $\mathbf{T}_{\mathbf{3}}$ & $\mathbf{T}_{\mathbf{4}}$ & $\mathbf{T}_{\mathbf{0}}$ & $\mathbf{T}_{\mathbf{1}}$ & $\mathbf{T}_{\mathbf{2}}$ & $\mathbf{T}_{\mathbf{3}}$ & $\mathbf{T}_{\mathbf{4}}$ & $\mathbf{T}_{\mathbf{0}}$ & $\mathbf{T}_{\mathbf{1}}$ & $\mathbf{T}_{\mathbf{2}}$ & $\mathbf{T}_{\mathbf{3}}$ & $\mathbf{T}_{\mathbf{4}}$ \\
\hline Maize & 46.53 & 48.70 & 48.70 & 50.87 & 50.87 & 49.41 & 51.35 & 51.35 & 52.51 & 52.51 & 54.05 & 55.60 & 55.60 & 57.15 & 57.15 \\
Soybean Meal & 40.10 & 35.54 & 35.54 & 30.98 & 30.98 & 37.80 & 33.41 & 33.41 & 29.70 & 29.70 & 32.45 & 28.40 & 28.40 & 24.35 & 24.35 \\
DORB & 5.00 & 9.50 & 9.50 & 14.00 & 14.00 & 3.50 & 8.00 & 8.00 & 12.50 & 12.50 & 3.50 & 8.00 & 8.00 & 12.50 & 12.50 \\
Vegetable Oil & 4.40 & 2.20 & 2.20 & 0.00 & 0.00 & 5.30 & 3.15 & 3.15 & 1.10 & 1.10 & 6.00 & 3.90 & 3.90 & 1.80 & 1.80 \\
DCP & 1.80 & 1.80 & 1.80 & 1.80 & 1.80 & 1.80 & 1.80 & 1.80 & 1.80 & 1.80 & 1.80 & 1.80 & 1.80 & 1.80 & 1.80 \\
LSP & 1.10 & 1.10 & 1.10 & 1.10 & 1.10 & 1.20 & 1.20 & 1.20 & 1.20 & 1.20 & 1.20 & 1.20 & 1.20 & 1.20 & 1.20 \\
Salt & 0.25 & 0.25 & 0.25 & 0.25 & 0.25 & 0.25 & 0.25 & 0.25 & 0.25 & 0.25 & 0.25 & 0.25 & 0.25 & 0.25 & 0.25 \\
Trace Mineral Premix & 0.15 & 0.15 & 0.15 & 0.15 & 0.15 & 0.15 & 0.15 & 0.15 & 0.15 & 0.15 & 0.15 & 0.15 & 0.15 & 0.15 & 0.15 \\
Vitamin Premix & 0.05 & 0.05 & 0.05 & 0.05 & 0.05 & 0.05 & 0.05 & 0.05 & 0.05 & 0.05 & 0.05 & 0.05 & 0.05 & 0.05 & 0.05 \\
DL-Methionine & 0.15 & 0.16 & 0.16 & 0.17 & 0.17 & 0.10 & 0.12 & 0.12 & 0.14 & 0.14 & 0.14 & 0.16 & 0.16 & 0.18 & 0.18 \\
L-Lysine & 0.07 & 0.15 & 0.15 & 0.23 & 0.23 & 0.04 & 0.12 & 0.12 & 0.20 & 0.20 & 0.01 & 0.09 & 0.09 & 0.17 & 0.17 \\
Choline Chloride 60\% & 0.10 & 0.10 & 0.10 & 0.10 & 0.10 & 0.10 & 0.10 & 0.10 & 0.10 & 0.10 & 0.10 & 0.10 & 0.10 & 0.10 & 0.10 \\
Toxin Binder & 0.10 & 0.10 & 0.10 & 0.10 & 0.10 & 0.10 & 0.10 & 0.10 & 0.10 & 0.10 & 0.10 & 0.10 & 0.10 & 0.10 & 0.10 \\
\hline
\end{tabular}

the highest value for serum albumin as compared to rest of treatment groups. Our results of albumin are in concurrence with the observation of other researchers (Ting and Balloon (1972), Hernandez et al. (2012). On the contrary Abudabos et al. (2012) did not observe any effect on serum albumin concentration fed diet low in ME and protein supplemented with lysine, methionine and threonine. The values for serum globulin was comparable and did not differ among the different groups. . Similarly Yuan et al. (2008) observed the addition of enzyme complexes had no significant effects on blood parameters. On contrary Awad et al. (2014) observed that reduction in protein level with amino acids supplementation had significantly increased serum globulin. The present study showed that feeding a low protein diet had lower blood urea nitrogen level $(\mathrm{P}>0.05)$ in treatments groups as compared to control one. There were significant differences among the treatments for fasting body weight, after bleeding weight of carcass, defeathering weight of carcass, eviscerate weight of carcass, and edible weight of carcass. Also significant differences were observed among the treatments for the dressing percentage, edible meat percentage, giblet percentage and abdominal fat percentage. The dressing percentage was significantly more in $\mathrm{T}_{0}, \mathrm{~T}_{1}$ and $\mathrm{T}_{2}$ group, however abdominal fat pad was found to be reduced in $\mathrm{T}_{3}$ and $\mathrm{T}_{4}$ group. Similar results were obtained by Raju et al. (1999) who observed increased abdominal fat with decreased CP contain of diet supplement with amino acid. Similarly, Panda et al. (2012) found a significantly lower abdominal fat percentage in the birds fed low energy diet supplemented with enzyme. However in contrast to the present result Zakaria (2010) found no significant differences in abdominal fat pad fed a diet supplemented with enzyme. Similarly, Youssef et al. 
(2011) found decreased in abdominal fat pad in the broiler chicken fed with enzyme supplemented diet. Further Cho (2012) found no significant effect in abdominal fat. Whereas, Awad et al. (2014) observed that the chicken receiving $16.25 \% \mathrm{CP}$ diet had non-significant change in abdominal fat weight.

\section{CONCLUSION}

Addition of synthetic amino acids with multi-enzyme with reduction of energy and protein up to 5 percent is found to be effective.

\section{REFERENCES}

Abudabos, A.M., Borges, C.A. Fritts and Waldroup, P.W. 2012. Effect of enzyme supplementation to normal and low density broiler diets based on corn-soybean meal.Asi. J. Anim. Vet. Adv., 7: 139-148.

Annongu El-Katcha I., Mosaad A. Soltan, Hany F. El-Kaney and El-Sayed Karwarie, R. 1997. Growth performance, blood parameters, immune response and carcass traits of broiler chicks fed on graded levels of wheat instead of corn without or with enzyme supplementation. Alexandria J. Vet. Sci., 40: 95-111.

Awad, A.R., J.L. Sell and Zimmerman, D.R. 2014. Effect of lowprotein diets on growth performance and body composition of broiler chicks. Poult. Sci., 81: 1156-1167.

Bureau of Indian Standards. 2007. Indian Standard, Poultry Feed Specifications ( $5^{\text {th }}$ version, IS: 1374, 2007) 3-6.

Cho, J.H., P.Y. Zhao and Kim, I.H. 2012. Effects of emulsifier and multienzyme in different energy density diet on growth performance, blood profiles, and relative organ weight in broiler chickens. J. Agri. Sci., 4: 187-194.

Cowieson and Ravindran. 2008. Recent advances in research on enzymes for poultry diets. Poult. Sci., 90: 2013-2023.

Dozier, L.R.B., Sakomura, N.K., Barbosa, N.A.A., Bonato, M.A., Kawuauchi, I.M., Fernandes, J.B.K. and Costa, F.G.P. 2007. Corn and soybean meal metabolizable energy with the addition of exogenous enzymes for poultry. Brazilian $J$. Poult. Sci., 11: 51-55.

Duccan Multiple Range Test. 1995. Biometrics, 11: 1-42.

Garcia, M.I., Latorre, M.A., García, M., Lázaro, R. and Mateos, G.G. 2000. Heat processing of barley and enzyme supplementation of diets for broilers. Poult. Sci., 77: 90-93.
Hernandez, F., Lopez, M., Martinez, S., Megias, M.D., Catala, P. and Madrid, J. 2012. Effect of low-protein diets and single sex on production performance, plasma metabolites, digestibility, and nitrogen excretion in 1- to 48-day-old broilers. J. Poult Sci., 91: 683-692.

Kidd, M.T., Morgan, G.W. and Price, C.J. 2001. Enzyme supplementation to corn and soybean meal diets for broilers. J. Poult. Res., 10: 65-70.

Malmo, G.A., Bolu, S.A., Olutade, S.G. and Suleiman, Z.G. 2013. Effects of feeding low protein diets with methionine and lysine supplementation on the performance and nitrogen economy of broilers. Res. Opin. Anim. Vet. Sci., 3: 330-334.

Panda, A.K., Lavanya, G. Reddy, E.P.K. Rao and Raju, M.V.L.N. 2012. Effect of dietary Supplementation of enzymes on performance of broiler chickens in maize-soybean meal based diet. Ani. Nut. Feed Tech., 12: 297-303.

Raju, M.V.L.N., Sodagopan, V.R., Sundar, G.S. and Rao, S.V.R. 1999. Performance of broiler fed low dietary protein levels with or without supplementation of lysine and methionine. Ind. J. Anim. Nut., 16(3): 194-198.

SPSS. 2009. Statistical Package for the Social Sciences Version, 17.

Summers, S.J., Leeson, D. and Diane Spratt. 1988. Yield and composition of edible meat from male broilers as influenced by dietary protein level and amino acid supplementation. Can. J. Anim. Sci., 68: 241-248.

Ting, K.C. and Bolloun, S.L. 1972. Effect of protein level and methionine supplementation on several metabolic responses in turkey. Poult. J. Nut., 102: 681-688.

Youssef, A.W., Hassan, H.M.A., Ali, H.M. and Mohamed, M.A. 2011. Performance, Abdominal fat and Economic efficiency of Broilers fed different energy levels supplemented with xylanase and amylase from 14 to 40 days of age. World $J$. Agri. Sci., 7(3): 291-297.

Yuan, J., Yao, J., Yang, F., Yang, X., Wan, X., Han, J., Wang, Y., Chen, X., Liu, Y., Zhou, Z., Zhou, N. and Feng, X. 2008. Effects of supplementing different levels of a commercial enzyme complex on performance, nutrient availability, enzyme activity and gut morphology of broilers. Asi-Aus $J$. Anim. Sci., 21(5): 692-700.

Zakaria, H.A.H., Mohammad, A.R. Jalal and Majdi Abu Ishmais, A. 2010. The influence of supplemental multi-enzyme feed additive on the performance, carcass characteristics and meat quality traits of broiler chickens. Int. J. Poult. Sci., 9(2): 126133 